\title{
Announcement
}

\section{6th World Congress of the International Union of Angiology}

September 13-18, 1992, Paris, France Palais des Congrès of Paris

Topics: Arterial, venous, microcirculatory and lymphatic diseases.

Topics specific to hemostasis: Venous thromboem-bolic disease: Biological aspects: The congenital deficiencies in antithrombin III, protein C and protein S: clinical aspects; The congenital deficiencies in antithrombin III, protein $\mathrm{C}$ and protein S: genetical aspects; Is hypofibrinolysis a risk factor for venous thrombosis? Antiphospholipids antibodies and thrombosis; Hormonal treatment and thrombosis; D-Dimers and the diagnosis of venous thromboembolism; The new markers of hypercoagulability: a critical appraisal for clinical use. Antithrombolic therapy: the state of the art: Hepa-rins and prevention of deep vein thrombosis; Anti-platelet agents and prevention of deep vein thrombosis; Anticoagulant treatment of deep vein thrombosis: the acute phase; Anticoagulant treatment of deep vein thrombosis: the prevention of recurrences; New anti-thrombotic agents.

Low molecular weight heparins (LMWH): LMWH: mechanisms of action; How to monitor a treatment with LMWH; LMWH and prevention of deep vein thrombosis: a meta analysis of clinical trials; LMWH and the treatment of established deep vein thrombosis; Tolerance of LMWH.

Deadline for submission of abstracts: December 31st, 1991.

Official language: English.

Scientific Secretariat:

Prof. H. Boccalon

CHU Rangueil

Service d'Angiologie

1 , Avenue J.-Poulhès

F-31054 Toulouse Cédex (France)

Phone: (33) 61322945 Fax: (33) 61322634

Administrative Secretariat:

SOCFI Angiology Congress 14, rue Mandar F-75002 Paris (France)

Phone: (33) 42338994 Fax: (33) 40260444

52 